for students of all kinds, especially during the naturally inactive season of the year.

Its usefulness as a method of storage is, in this case at least, rather limited; for another set of gemmules similarly planted out early in May (by which date young sponges apparently developing from gemmules had already been found in Loch Lomond by Dr. Harry D. Slack) gave no development at all in three weeks of 22 Ephydatia gemmules still kept in the refrigerator, and 2 Spongilla out of 26
gemmules (23 Spongilla and 3 Ephydatia) kept on the laboratory bench.

Incidentally, little sponges grown in this way are excellent for showing the economy of a sponge and the activities of its constituent cells, including the action of the contractile vacuoles. A paper on this subject is in the press. Formation of young spicules could be observed from about the ninth day of the December cultures in Spongilla; and, even with no special attention to feeding the spongelets or to conditioning the water, oscula were developed, and the currents maintained by the choanocytes could be demonstrated particles or coloured food. The little sponge spreading out over the coverslip makes a beautiful permanent preparation.

Department of Zoology,
University of Glasgow.

Sept. 1.

\section{Enamel Formation in the Rat's Incisor Tooth}

Accounts have been already published of the effects of vitamin D, alteration of the $\mathrm{Ca}: \mathrm{P}$ ratio of the diet, and dietary restriction, upon the dentin of the incisors of rachitic rats $^{1}$. It was noted during this work that the formation of organic enamel was sometimes upset by these procedures in animals on the Steenbock and Black rachitogenic
diet of high $\mathrm{Ca}: \mathrm{P}$ ratio; but that the organic enamel of animals made rachitic by low $\mathrm{Ca}: \mathrm{P}$ ratio diets was scarcely ever affected. The fact that organic enamel formation in rats on a high $\mathrm{Ca}: \mathbf{P}$ ratio diet is easily upset by various metabolic changes has been confirmed by recent experiments, which were undertaken in a different way and originally for another purpose ${ }^{2}$ : after twenty-eight days on the usual Steenbock and Black diet, the animals were subjected to dietary restriction for $5-6$ days. By this time it was found by examining a control rat that the epiphyses showed a well-marked 'line test' response. The remainder of the litter was then placed back on to full Steenbock and Black diet, and rats were killed and examined at intervals up survival. Five litters of rats were treated in this way.

Examination of the upper incisor teeth at the third day of re-feeding showed that organic enamel formation had stopped. By the sixth day of re-teeding and sometimes earlier, the formation of organic enamel had begun again, often very irregularly at first, with globular material replacing proper enamel matrix. The old organic enamel matrix was not further laid down. This process is illustrated in the accompanying flgure. The drawing was made from the tooth of rat re-fed for twelve days. In some cass, as here the proximal of a of the old organic enamel was overlaid with globular material, and Measurements of the distance from the proximal end of the old

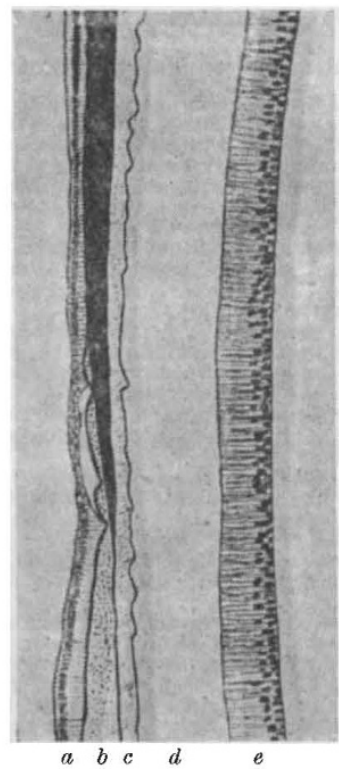

DIAGRAM, BASED ON A CAMERA LUCIDA DRAWING, OF THE ORGANIC ENAMEL AND DENTIN OF A RACHITIC RAT. $(\times 66$. $) \quad a=$ AMRLOBLASTS, $b=$ ORGANIC ENAMEL, $c=$ CALCIFIED DENTIN, $d=$ PREDENTIN, $e=$ ODONTOBLASTS. THE OLD ORGANIO ENAMEL IS DRAWN BLACK, AND THE GLOBULAR MATERIAL AND NEW ORGANIC ENAMEL ARE STIPPLED. THE PREDENTIN IS WIDE AS IS USUAL WITH THIS TYPE OF DIET. THE GAP BETWEEN THE GLOBULAR MATERIAL AND THE AMELOBLASTS IS AN ARTEFACT enamel to the curve of Hertwig's epithelial sheath were made in four of the litters, and the distances plotted against the time of the events of the experiment. Extrapolation showed that enamel formation had stopped at the time the full diet was restored. The serum calcium, which was initially high, as is usual, fell somewhat when the animals diet was restricted, and rose again when the full diet was given.

The formation and maturation of the organic enamel were affected in different ways. The old enamel remained the same as when amelogenesis stopped, but calcified at about the same place along the tooth as it would have done if left undisturbed. It became slightly wider just prior to calcification, but was much narrower than normal at this point in the animals killed late in the experiment. The old proximal organic enamel retained the honeycomb structure typical of the deposition of new enamel (Wasserman ${ }^{3}$ ), although no more was formed and the ameloblasts over the old enamel were of the short variety. Once new enamel formation was established, it was accompanied by the presence of the normal tall ameloblasts associated with the formation of enamel (Diamond and Weinman ${ }^{4}$, Wasserman ${ }^{3,5}$ ). The fact that the old organic enamel is associated with short ameloblasts and that it matures and calcifies, but littie more is formed, is consistent with Wasserman's concept of these cells being active in enamel maturation only. The chief effect of the dietary change on the enamel organ existing at the time was to prevent the further formation of tall ameloblasts and to reduce those already present. As a result, enamel formation stopped, but maturation appeared to proceed normally. In certain places, especially at the proximal end of the old enamel, the ameloblasts were changed into small amorphous cells. Here granular material was laid down, but no enamel matrix, the

The changes described above are similar in some ways to those found by Weinman' after strontium injections. In his experiments, found by Weinmans after strontium injections. In his experiments, however, the hypoplastic enamel matrix did not undergo maturation,
Many other nutritional and endocrine conditions, such as magnesium or vitamin A deficiency or parathyroidectomy, also affect amelogenesis, vitamin A deficiency or parathyro
but not in the same way as here.

$$
\begin{gathered}
\text { Department of Physiology, } \\
\text { Medical School, } \\
\text { University of Cape Town. }
\end{gathered}
$$

$$
\text { Aug. } 26 .
$$

${ }^{1}$ Irving, J. T., J. Physiol., 108, 9 (1944) ; 104, 253 (1946) ; 105, 16 $(1946)$

${ }^{2}$ Bailie, J. M., and Irving, J. T., unpublished results.

${ }^{4}$ Diamond, M. F. J Dent. Res., 23, 463 (1944). (New York: Columbia Úniversity, 1940).

5 Wasserman, F., J. Dent. Res., 20, 254 (1941).

' Weinman. J. P., J. Dent, Res., 22, 210 (1943).

\section{Tests for Rh Isosensitization of Red Cells in the Newborn}

Coombs, Mourant and Race ${ }^{1,2,3}$ have described an indirect method for the detection of weak and 'incomplete' $R$ h agglutinins in human serum, and a direct method for the detection of in vivo isosensitization of red cells in babies with hæmolytic disease. The tests have been found to work equally well with the following rabbit antisera after absorption with $A, B$ and $O$ cells : (1) rabbit anti-human-pseudoglobulin; (2) rabbit anti-human-globulin; (3) rabbit anti-humanwhole-serum. In the direct method the red cells of the baby are freed from serum by washing three times in a large volume of saline, a $2-5$ per cent cell suspension in saline is then prepared and a drop of human-serum. Cells which have been sensitized to the $R h$ factor show

The principle of the test has been explained on the basis that sensitized cells have antibody globulin adsorbed at some points on their surface and that when these cells are brought into contact with their surface and that when these cells are brought into conta

The test as described by the authors is simple and efficient, and will, no doubt, be utilized later as a routine test in the better equipped maternity hospitals to detect sensitization of the red cells of newborn babies. The use of this test offers a new fleld of research in various diseases for blood workers which they, no doubt, will be quick to grasp. The only difficulty the average laboratory worker will have to meet is the preparation of a high titre anti-human serum in rabbits, and the satisfactory absorption of this serum with normal $A, B$ and $O$ cells to remove the hetero-agglutinins for these cells. The test serum may, of course, be used at a dilution beyond the point at which the hetero-agglutinins are no longer active for normal cells but at which the serum agglutinates sensitized cells. This, of course, is a method of testing for potency any anti-human serum prepared
in the rahbit, particularly with successive trial bleeds. Red cells in the rahbit, particularly with successive trial bleeds. Red cells blood to two drops of glucose-citrate and two drops of anti- $R h_{0}$ 'blocking' or 'incomplete' serum. The mixture is stood for one hour at $37^{\circ} \mathrm{C}$., or room temperature, and the cells washed with saline and then re-suspended in saline to give a concentration of $2-5$ per cent. The actual testing may be carried out on slides or tiles.

While work on this test was being conducted at these Laboratorie it was decided to flnd out if the test would give positive results only with rabbit anti-human serum, and not with rabbit anti-sera prepared with the serum of various animals. This work was facilitated by having available small quantities of various precipitating sera which had been prepared in rabbits by Mr. J. J. Graydon and Mr. E. F. Woods during 1943-44 for use by Australian research workers in malaria studies. The methods of preparation quoted are those used by Graydon and Woods, to whom I acknowledge my gratitude for the serum samples and for the details of preparation. Two methods of preparin the serum antigens for rabbit immunization were employed.

(1) An alcohol precipitation, by mixing $40 \mathrm{ml}$. serum, $160 \mathrm{ml}$. saline and $500 \mathrm{ml}$. absolute alcohol. The mixture was stood at $5^{\circ} \mathrm{C}$. or room temperature for $1-2 \mathrm{hr}$., centrifuged, and after the removal of the supernatant the deposit was re-suspended in normal saline equa 